\title{
Enhancing Geoscience Education Within a Minority-Serving Preser- vice Teacher Population
}

\author{
Katherine K. Ellins ${ }^{1, a}$ and Hilary Clement Olson ${ }^{1}$
}

\begin{abstract}
The University of Texas Institute for Geophysics and Huston-Tillotson University collaborated on a proof of concept project to offer a geoscience course to undergraduate students and preservice teachers in order to expand the scope of geoscience education within the local minority student and teacher population. Students were exposed to rigorous Earth science materials, geoscientists conducting cutting-edge research, headliner topics, and pedagogical approaches to teaching. An evaluation of the data reveal that the course received mixed, but overall positive reviews and that student performance was mixed. Pre- and posttest results indicate that students made only modest gains. Half of the students performed at levels that matched our expectations and will be able to apply the geoscience knowledge and skills that they learned in an elementary school setting. The course contributed to the preparation of minority teachers to teach Earth science in Texas, filling a critical need. The authors, in collaboration with a minority-serving institution and as part of the preparation for a preservice teacher program, benefited from the experience; they subsequently applied the lessons learned to a program of professional development for minority-serving science teachers, the TeXas Earth and Space Science (TXESS) Revolution. (c) 2012 National Association of Geoscience Teachers. [DOI: 10.5408/11-229.1]
\end{abstract}

Key words: Historically Black College and University (HBCU), diversity, undergraduate course, instruction, geoscience education

\section{INTRODUCTION}

The University of Texas Institute for Geophysics (UTIG), a research unit within the Jackson School of Geosciences at The University of Texas at Austin, and Huston-Tillotson University (HTU), a minority-serving Historically Black College and University (HBCU) located in Austin, collaborated on a proof of concept project in 2006 to expand the scope of geoscience education within the local minority student and teacher population. The idea for the UTIG/HTU "geodiversity" project arose out of interactions between UTIG researchers and HTU faculty who had been brought together by a series of Integrated Ocean Drilling Program Distinguished Lectures hosted by HTU. The project involved three elements: (1) a preservice teacher component designed to augment the ability to teach Earth science in Texas; (2) a summer workshop for Austin-based, minority-serving, inservice teachers to further their Earth science professional development; and (3) a K-12 student education initiative to expand HTU's Austin PreFreshman Engineering Program, an ongoing immersive mathematics/science summer program, to include a fourth year centered on geoscience. This paper reports on the preservice teacher preparation component carried out through a semester-long course, "Special Topics in the Geosciences," taught in spring 2006 at HTU. The course targeted preservice science teachers as well as other undergraduate students majoring in education and STEM (science, technology, engineering and mathematics) disciplines. The authors, as well-intentioned novices, en-

Received 20 November 2009; revised 21 September 2011; accepted 24 October 2011; published online 16 February 2012.

${ }^{1}$ The Institute for Geophysics, Jackson School of Geosciences, The University of Texas at Austin, Mail Code R2200, J.J. Pickle Research Campus, 10100 Burnet Road, Austin, Texas 78758, USA

${ }^{a}$ Author to whom correspondence should be addressed. Electronic mail: kellins@ig.texas.edu countered a number of unanticipated situations, which are discussed in this paper.

UTIG's primary mission is to investigate the dynamic geophysical processes that influence Earth's structure, environment, and climate. Recognizing the importance of collaboration between research institutions and the K-12 educational system, however, UTIG researchers also carry out projects aimed at improving the quality of $\mathrm{K}-12$ geoscience education throughout Texas. HTU, a private four-year institution with an annual enrollment of about 700 students, is one of eight HBCUs in the state of Texas, with 105 HBCUs nationwide (United States Department of Education, 2009). The United Negro College Fund reports on its Web site that although HBCUs make up only 3\% of institutions of higher education nationwide, they graduate $20 \%$ of all African American students enrolled in four-year colleges and $50 \%$ of African American public school teachers. Half of African Americans who graduate from HBCUs go on to graduate or professional schools (United Negro College Fund, 2011).

\section{RATIONALE}

Programs aimed at improving $\mathrm{K}-12$ science education to prepare precollege students-the nation's future human capital-for careers in STEM have grown in response to a decline in the number of U.S. scientists and engineers (Committee on Prospering in the Global Economy of the 21st Century, 2007; National Academies, 2010). Programs to strengthen $\mathrm{K}-12$ science education increasingly occur concomitantly with efforts to broaden diversity by targeting demographic groups that have not previously participated in STEM careers in order to achieve a workforce that corresponds to the changing demographics of the nation (George et al., 2001; National Science Board, 2003; National 
Science Foundation [NSF], 2005; Tapping America's Potential, 2005; Riggs and Alexander, 2007).

The rationale for the project was rooted in three factors: (1) the special need for the geosciences to attract and retain ethnic minorities as identified by Hall and Johnson (2001), Czujko and Henly (2003), Karsten (2003), and Huntoon and Lane (2007); (2) the increasing minority population in Texas; and (3) the results of student performance on the Texas Assessment of Knowledge and Skills (TAKS) for 2003, 2004, and 2005. Among the state's current K-12 student population, $14 \%$ are African American and $48.6 \%$ are Hispanic (Texas Education Agency, Division of Performance Reporting, 2011). Of the 300,000 teachers in Texas in 2006-2007 when this project was carried out, 9.3\% were African American, 20.8\% were Hispanic, and 68.5\% were white, a distribution that does not reflect the demographics of the student population and underscores the need to prepare more minority teachers (Texas Education Agency, Division of Performance Reporting, 2007). In 2004 and 2005, only $49 \%$ of African American students and 53\% of Hispanic students met the TAKS objectives in science as compared with $81 \%$ of white students. In Texas, where the total contribution of Earth science-related industries to the economy is at least US\$ 150 billion annually and half a million jobs (Texas Education Agency Earth Science Task Force, 2003), Texas students' performance on Earth science tests is far lower than any of the other science disciplines tested. In fact, at the time of this project, Texas students were failing the Earth science assessments administered to public school students in grades 5, 10, and 11 (C. Comer, former Director for Science of the Texas Education Agency, personal communication). To reverse these trends, Earth science teacher preparation programs for minorities are required. The special topics course offered in 2006 at HTU represented a small step in that direction.

\section{ACADEMIC GOALS AND APPROACH}

The "Special Topics in the Geosciences" course was originally designed for middle and high school preservice science teachers and undergraduate STEM majors. However, the course did not attract these students. Instead, nine elementary school-level preservice teachers, one computer science major, and one psychology major enrolled in the course. Of the 11 students in the course, seven were African American, one was African, two were Hispanic, and one was white (this student eventually withdrew for health reasons). Although the course did not attract our desired target audience, poor student performance in science on national and state assessments motivated us to modify the course that we had designed to better serve the elementary schoollevel preservice students who had enrolled in the course, thus improving the science preparation of elementary teachers in our local area. In 2006, Grigg et al. (2006) reported that about one-third of fourth grade students in the U.S. performed at the proficient level on recent science assessments at the national level although small gains had been made by minority students. At the state level, the results of the TAKS for 2003, 2004, and 2005 indicated that Texas students were failing the grade-5 Earth science assessments administered to public school students (C. Comer, personal communication).
Our goals were (1) to engage students in collaborative, active learning in order to enhance their understanding of Earth science concepts and (2) to impart established best teaching practices as summarized by Loucks-Horsley et al. (1998), Kaser and Bourexis (1999), and Boyd et al. (2003) by modeling ways that we wanted these preservice teachers to teach. To achieve our objectives, we replaced the traditional lecture format typical of most undergraduate Earth science introductory courses with a less structured approach that minimized direct teaching to both deliver Earth science content and teach the skills required to carry out scientific investigations. We emphasized guided-inquiry and integrated examples of project-based learning, as well as instructional strategies such as the 5-E model, into our delivery (Bybee et al., 2006).

The class met two days a week for two hours during which students worked in teams on inquiry-based, handson learning activities developed previously for K-12 teachers with NSF and Texas Education Agency support. The activities, which are listed in Table I, highlight contemporary and important topics in the geosciences (geologic time, tectonic processes, extreme events, evolution, climate change, sea-level fluctuations, and hydrologic processes), involve the manipulation of real geoscience data, and require computer skills. They also integrate technologies from geodesy, geophysics and geology, scientific ocean drilling, remote sensing, and the Internet into science and mathematics learning designed to give the students an increased understanding of recent developments in Earth science. In addition, the activities are aligned with the National Science Education Standards and the Texas Essential Knowledge and Skills (TEKS) for Geology, Meteorology, and Oceanography. Earth and Space Science replaced Geology, Meteorology, and Oceanography as the preferred Texas high school Earth science course in fall 2010 (National Research Council, 1996; Texas Education Agency, 2009).

In addition to hands-on activities, we incorporated complementary resources, such as visualizations and Webbased tutorials and interactive tools, to help the students keep abreast of recent science and technology developments in Earth science. Six faculty and/or research scientists from the Jackson School of Geosciences gave presentations to reinforce course content and expose students to cutting-edge geoscientists and their research. We included a local geology field trip to provide our students with opportunities to apply knowledge gained in the classroom (i.e., the fundamental principles of stratigraphic analysis) to the real world. Our objective was to use the experience to model what real geoscientists do in the field-observe, make measurements, record information, and apply theoretical knowledge to a field setting-so that these students would be able to lead field trips with their students that surpass traditional "showand-tell" experiences.

\section{OUTCOMES}

\section{Assessment of Student Performance}

We assessed student performance on the basis of homework assignments (20\% of grade), two quizzes designed to test content knowledge and concept comprehension (20\% of grade), participation (10\% of grade), a midterm project ( $25 \%$ of grade), and a final project $(25 \%$ of grade). Students were allowed to drop the lowest quiz grade, 
TABLE I: Description of curriculum modules with learning activities used in "Special Topics in the Geosciences" and by guest presenters.

The Geologic Time module has learning activities that explore relative and absolute time, how fossils are used to tell time, radioactive dating, the concepts of faunal succession and deep time, new theories about Earth's history that emerged from understanding geologic time, and the different geologic time scales (Ellins and Olson, 2000).

The Plate Tectonics module sets the stage for a discussion on scientific inquiry and hypothesis testing, and develops the fundamental concepts of plate tectonics. Several activities are based on the research of UTIG's global plate reconstruction project, PLATES, which models past and present tectonic plate movements and geologic environments (Ellins and Olson, 2000). Guest speaker: Dr. Kathryn Moran, University of Rhode Island Graduate School of Oceanography, The Arctic Coring Expedition (ACEX).

Earthquakes: Shake, Rattle, and Roll employs a combination of computer-based tutorials, kinesthetic activities, and guided exercises to help learners understand the basic structure of the Earth and how seismic waves propagate through the Earth. The module also includes learning activities related to the emerging field of forensic seismology (Ellins et al., 2002). Guest speaker: Dr. Clark Wilson, Department of Geological Sciences, Jackson School of Geosciences, University of Texas at Austin, GPS Technology and the EarthScope Plate Boundary Observatory (PBO) Experiment.

Raised Coral Reefs conveys the knowledge that our Earth is dynamic. Learners analyze radiocarbon and elevation data collected from raised coral reefs in the New Georgia Islands to calculate rates of tectonic uplift and develop conceptual models to explain the uplift patterns that emerge from the data (Ellins and Olson, 2000). Guest speaker: Dr. Ann Molineux, Texas Natural Science Center, University of Texas at Austin, Modern and Ancient Coral Reefs of Texas.

Tsunamis: Walls of Water contains activities based on past tsunami events in order to explain the geologic processes that produce tsunamis and encourage consideration of appropriate mitigation strategies. Quantitative exercises that determine factors such as tsunami travel times, wave heights, run-up distance, and other critical parameters are included (Ellins et al., 2002).

Asteroid Impacts: Chicxulub and the K-T Boundary. Activities are designed to encourage learners to investigate the Chicxulub impact hypothesis with gravity and seismic data from the Yucatan Peninsula and Gulf of Mexico, and document the K-T extinction event with microfossil data (Ellins et al., 2002; Svihla et al., 2004). Guest speaker: Dr. Sean Gulick, UTIG, Jackson School of Geosciences, Imaging the Chicxulub Impact Crater.

Hurricane Mitch: An Exercise in Geohazards. Exercises utilize digital elevation models and topographic cross-sections constructed from the Honduran airborne Light Detection and Ranging (LIDAR) data as well as storm data from the National Hurricane Center to highlight the natural hazards associated with major tropical storms-floods, landslides, storm surges, and high winds—and demonstrate the application of geographic information systems technology (GIS) as a tool in disaster mitigation and emergency planning (Smyth et al., 2003).

Sea-Level History-The Ever Changing Climate on Earth examines sea-level fluctuations, climate change, types of marine sedimentary deposits, and stratigraphy using data contained in sediment cores from several different projects in the Gulf of Mexico and offshore New Jersey. Learning activities include a climate analysis using planktonic foraminifera and the interpretation of past water depths and ancient environments from fossil foraminifera evidence (Ellins and Olson, 2000). Guest speaker: Dr. John Goff, UTIG, Jackson School of Geosciences, Changing Sea Level.

Climate Change. Ocean Drilling Program (ODP) Site 1002D core data provides the basis for an activity that links core studies with the collapse of the Mayan civilization. In this activity, a subset of titanium concentration vs. core depth data obtained from the Cariaco Basin (offshore Venezuela) is plotted as a proxy for rainfall vs. time. When the students superimpose times of Mayan population collapse, they find a correlation with core data for drought occurrences-approximately 280 and 380 A.D. (i.e., Preclassic Abandonment) and a major drought from approximately 750 to 950 A.D. (i.e., Terminal Classic Collapse) (Rodgers et al., 2005). Guest speaker: Dr. Ginny Catania, UTIG, Jackson School of Geosciences, Diminishing Ice Sheets in Greenland and Antarctica.

and we also granted students extra credit for presenting material from the course at events such as "Expanding Your Horizons in Science and Mathematics" and UT Explore (an annual open house on the University of Texas campus). Class grades were determined using these measures.

We based the midterm project on a field trip to McKinney Falls State Park, situated in the Texas coastal plain just east of Austin, led by Jackson School of Geosciences professor, Dr. Leon Long. The rocks in the park reflect two stages in the geologic history of the region: (1) the deposition of shallow marine sedimentary and volcanic rocks of late Cretaceous age and (2) uplift above sea-level followed by erosion and downcutting by streams established across the land surface during Tertiary and Quaternary time. For their project, students worked in teams of three or four to create field trip guides for elementary school-level students, teachers, or parents. We urged them to focus on only one aspect of the local geology and to use this as the centerpiece of the field trip guides they developed. Students aligned the guides with the appropriate elementary school-level TEKS and gave PowerPoint presentations about their respective projects to the class.

For the final project, "Science and a Movie," students worked in teams of two or three (1) to review a popular movie that contained geoscience information, (2) to develop a standards-aligned lesson plan to illustrate how they would teach the science concepts in the film and dispel misinformation put forth in the movie, (3) to interview a real scientist in a field closely related to the movie topic to determine how closely matched the real-life experience as a scientist was to the character(s) portrayed in the movie, and (4) to deliver a 20 -min presentation on the three components of the project to the class. The evaluation of team projects consisted of three parts: (1) instructor evaluation of oral presentations, (2) instructor evaluation of written reports, and (3) student peer-evaluation of their own group project, their participation level, and fellow team members' contributions. The peer evaluation was designed to give the students' perspectives on the efforts of different group members. We developed it in response to students' initial discomfort with teamwork 
and concerns about the disparity in participation among group members, an observation made by other researchers in the field (Bertog, 2007). We used a questionnaire for students to evaluate their own performance on group projects and the performance of team members.

\section{Discussion of Student Performance}

Student performance was mixed. Five of the 11 students performed at levels that matched our expectations, and we are confident that they are competent to apply the geoscience knowledge and skills that they learned in the course to an elementary school setting. One of these five students stood out as having good command of the content as well as the ability to use inquiry in her teaching. A second student in this category was extremely creative in transforming our inquiry-based activities to the level she would be teaching (elementary school), although she did not always have the content as accurate as we would have liked. A third student from this same group was characterized by motivation and interest below the potential of her ability. She failed to make the connection during the course of how she would apply our activities in a classroom setting. She is currently teaching as a high school aide, however, and has written one of us to say how much she benefited from the course. Now, as a practicing teacher, she sees the applications of what she learned in our course.

Of the remaining six students, two did very poorly; one withdrew due to illness, and three passed with average grades. Two of these six students were not preservice students. One was a computer science major and very capable, but did not put forth the effort to match his ability. The other of the two was a psychology major, a mature student and immigrant who had received his pre-university education in sub-Saharan Africa. This student was intensely interested and worked very hard; however, he lacked some of the fundamental analytical skills to master the content. Three of these six students were preservice teachers and did not perform well. It is our consensus that they would not be competent to teach fundamental geoscience concepts to elementary students after taking only our course. One of these students was burdened by multiple obligations: a fulltime job, a child, care of three brothers, and membership in an athletic team.

The student who most excelled in the course worked at UTIG during the summer and fall 2006 as an undergraduate research intern and attended the fall American Geophysical Union meeting to participate in the Geophysical Information for Teachers workshop and to present on her experience as an intern at UTIG (Putman et al., 2006). Dr. Deanna Mercer, Huston-Tillotson Associate Professor of Education and a faculty advisor to this student, commented: "[student's] experience in the course was a turning point in her total development academically and professionally. At HTU, we noticed her enthusiasm and natural propensity for this area of study [geoscience]. She developed a knack for lesson planning and was comfortable presenting information to others." We remain in touch with this teacher who is now a science education specialist at a magnet school in Houston, Texas.

\section{Project Evaluation}

We collected data from the participants for the purpose of evaluating the quality of the course instruction and value of the materials and approaches used. Assessment tools include (1) pre- and posttests of geoscience content knowledge (confidential); (2) surveys to assess the course content, our effectiveness as instructors, quality of guest presenters, achievement of the project goals, and areas for potential improvement (confidential); and (3) a focus group discussion facilitated by an HTU faculty member who was not directly connected with the UTIG/HTU geodiversity project. Students who took part in the survey and focus group discussion received a \$15 gift card.

\section{Pre- and Postcourse Knowledge Assessment}

We developed and administered a pre- and postcourse knowledge assessment containing 60 questions to determine the degree to which we are able to impart geoscience knowledge and promote inquiry and higher-order thinking skills as outlined by Bloom (1956). Bloom's taxonomy proved a useful structure in which to categorize questions within particular levels (knowledge, comprehension, application, analysis, synthesis, and evaluation) and served as a means to gauge student progress to the highest levels of understanding. We designed the test so that most questions require essay answers and diagrams to demonstrate a learner's ability to engage in critical thinking. An example of a subset of questions is shown in Table II. A comparison of the preand posttest results reveals that students made only modest gains (Fig. 1). It is difficult to assess the cause(s) of this outcome. It may reflect one or a combination of several situations: failure on our part to help students develop the higher-order thinking required to do the learning activities, students' lack of fundamental preparation in analytical skills (basic pre-high school-level mathematics tutorials had to be inserted throughout the course, e.g., the concept of percent), or problems with the pre- and posttest itself. In the latter case, we administered the same test both at the start of the course and at the end during the time slot allocated for the final exam. We suspect that because performance on the posttest did not count toward a final grade, students were not motivated to expend much effort in completing so many questions. In fact, three students chose not to take this posttest. Research conducted by Barry et al. (2010) shows that test scores may not truly reflect the abilities of examinees in cases when there is little or no personal consequence for the test taker.

\section{Surveys and Focus Group Discussion}

Seven of the eleven students in the course agreed to complete the surveys. These results reveal that the course received mixed, but overall positive reviews. As instructors, we were well-reviewed, receiving an average overall score of 26.2 out of 35 total points. Course materials received an average overall score of 24.7 out of 35 total points. A composite score of 21.8 out of 35 was given for the pace of the program, usefulness of guest presenters, relevance to teaching mathematics concepts, integration of computer activities, and integration of the Internet and related skills.

The results of the participant self-evaluation survey (Table III) indicate that the students liked working together, despite their initial discomfort with teamwork. However, as a group they rated themselves lowest on the measure of tutoring others, which suggests that the collaboration achieved for the midterm and final projects did not extend to in-class activities and homework assignments. In general, students rated their abilities and performance during the 
TABLE II: Example questions for pre- and postcontent knowledge and skills assessment.

\begin{tabular}{|c|c|c|c|c|c|c|}
\hline \multirow{2}{*}{$\begin{array}{l}\text { Example Questions for Pre- and Post-Content Knowledge and Skills } \\
\text { Assessment }\end{array}$} & \multicolumn{6}{|c|}{ Bloom's Taxonomy Classification $^{1}$} \\
\hline & K & $\mathrm{C}$ & A1 & A2 & S & $\mathrm{E}$ \\
\hline \multicolumn{7}{|l|}{ A. Define the following } \\
\hline Tides & $X$ & & & & & \\
\hline Exfoliation dome & $X$ & & & & & \\
\hline Cretaceous & $X$ & & & & & \\
\hline Aquifer & $X$ & & & & & \\
\hline P-Wave & $X$ & & & & & \\
\hline \multicolumn{7}{|l|}{ B. Describe the contributions of the following important Earth scientist to the field. } \\
\hline Harry Hess & $X$ & & & & & \\
\hline \multicolumn{7}{|c|}{ C. Determine whether the following statements are TRUE or FALSE. Elaborate on each of the statements. } \\
\hline Earth's magnetic poles reverse periodically. & & $X$ & & & & \\
\hline $\begin{array}{l}\text { Earthquakes around the world do not occur in a pattern but are } \\
\text { scattered randomly. }\end{array}$ & & $X$ & & & & \\
\hline \multicolumn{7}{|l|}{ D. Provide brief answers to the following (you may use illustrations): } \\
\hline $\begin{array}{l}\text { Where on Earth would you expect mountain building, earthquakes, and } \\
\text { volcanism? Give an example of each from a different geographic } \\
\text { location. }\end{array}$ & & $X$ & & & & \\
\hline $\begin{array}{l}\text { Do you think that the ocean floor will look the same } 10 \text { million years } \\
\text { from now? Explain. }\end{array}$ & & & 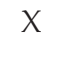 & & & \\
\hline $\begin{array}{l}\text { Enchanted Rock is a well-known geological feature in central Texas. } \\
\text { Provide a detailed classification of the rock of which Enchanted Rock is } \\
\text { composed and explain its domed shape. }\end{array}$ & & & 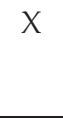 & & & \\
\hline $\begin{array}{l}\text { Hurricanes and tropical storms are often referred to as "nature's safety } \\
\text { valves." Explain how these systems form, and what this statement } \\
\text { means. }\end{array}$ & & & & $\mathrm{X}$ & & \\
\hline $\begin{array}{l}\text { Would you expect to see a correlation between rainfall and spring flow } \\
\text { at Barton Springs? Explain. }\end{array}$ & & & & $X$ & & \\
\hline $\begin{array}{l}\text { Describe the potential effects of a large meteorite or asteroid impact on } \\
\text { Earth processes. In particular, focus on (a) the atmosphere, (b) climate, } \\
\text { and (c) plants and animals. }\end{array}$ & & & & & $X$ & \\
\hline $\begin{array}{l}\text { How vulnerable is Barton Springs to pollution? Describe the impacts } \\
\text { contaminated water would have on humans depending on the Edwards } \\
\text { Aquifer for water. Describe the environment impacts contaminated } \\
\text { water would have on the flora and fauna of Barton Springs. }\end{array}$ & & & & & $X$ & \\
\hline $\begin{array}{l}\text { Scientists accept that the feature buried beneath Chicxulub on the } \\
\text { Yucatan Peninsula is an impact crater. One line of evidence comes } \\
\text { from gravity data collected over the area. Does this interpretation of } \\
\text { Chicxulub gravity data prove the existence of an impact crater at } \\
\text { Chicxulub? Why or why not? }\end{array}$ & & & & & & $\mathrm{X}$ \\
\hline $\begin{array}{l}\text { A local group is lobbying for the installation of a state-of-the-art } \\
\text { tsunami warning system in the Gulf of Mexico at a cost of } \$ 1.5 \text { billion. } \\
\text { A second group is vehemently opposed and claims that such a system } \\
\text { is unnecessary. Give reasons for each side's opinion. }\end{array}$ & & & & & & $X$ \\
\hline
\end{tabular}

${ }^{1}$ Abbreviations: $\mathrm{K}=$ Knowledge, $\mathrm{C}=$ Comprehension, $\mathrm{A} 1=$ Application, $\mathrm{A} 2=$ Analysis, $\mathrm{S}=$ Synthesis, $\mathrm{E}=$ Evaluation.

course highly, with an average overall score of 27 out of 35 total points.

An HTU faculty member facilitated a focus group discussion to solicit feedback on the course format, our instructional approach, and our objective of helping to broaden diversity in the geosciences by providing geoscience education to preservice teachers and undergraduate students at HTU. We were hoping for a more thorough understanding of the focus group's impression of bringing this course to HTU than we obtained. During the focus group, it appears that the discussion of diversity got off track. Excerpts from the student remarks during the focus group and our assessment/response to the comments are found in Table IV.

\section{Unique Challenges, Lessons Learned, and Lessons Applied Course Advertising}

The original target audience for this course was high school preservice science teachers and science majors. We relied on the host university, HTU, to handle recruitment; 


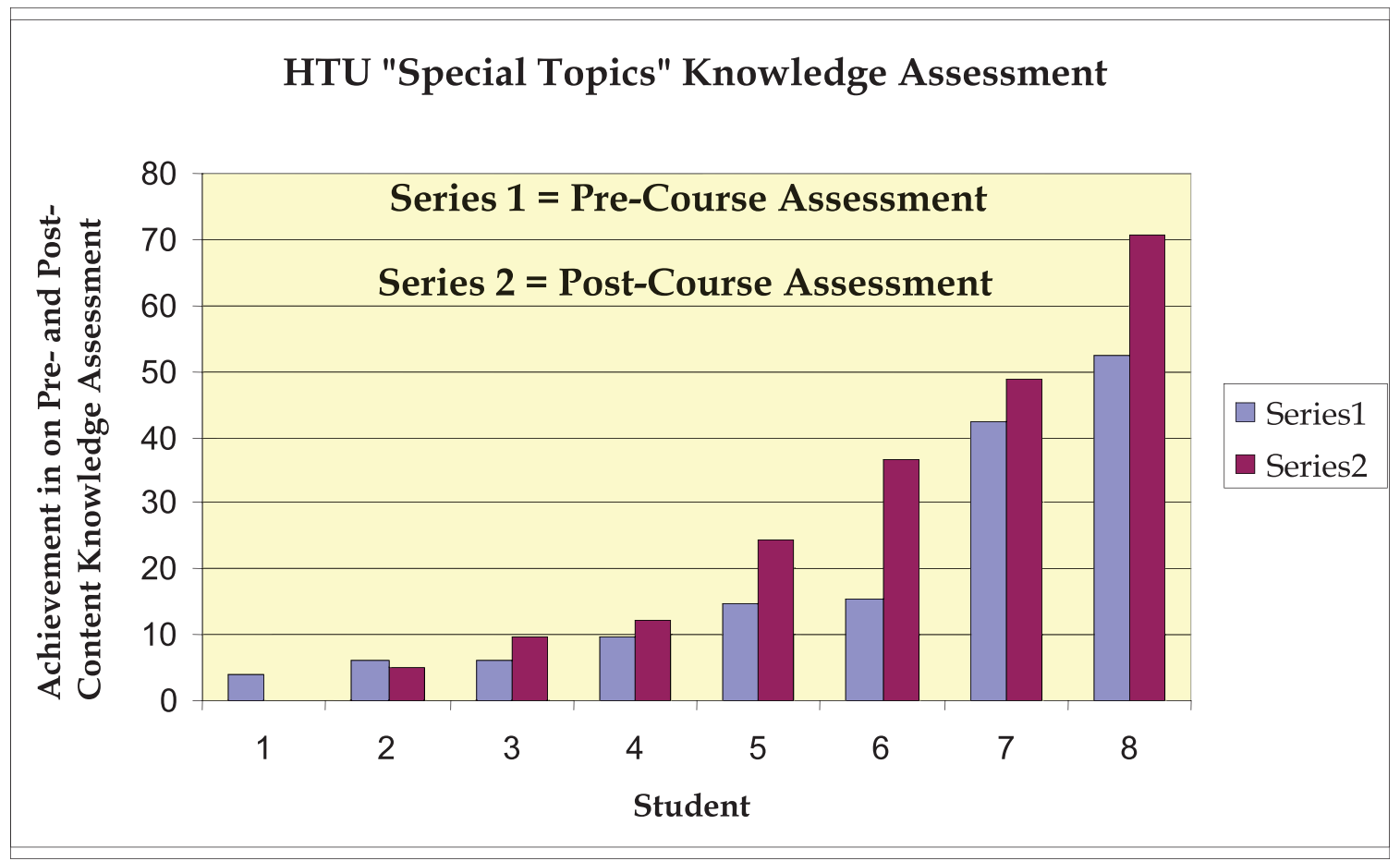

FIGURE 1: Results of pre- and postcourse content knowledge and skills assessment.

however, the course was not included in the printed course catalogue for the semester. Consequently, enrollment in the course was low at the beginning of the semester, and students were recruited for the course primarily from HTU education majors. Unfortunately, we were funded to offer the course for one semester only. If in the future the opportunity arises to offer the course a second time at a minority-serving institution, we would work with the host institution to mount a much more aggressive campaign to advertise the course and assist with marketing the course. Strategies could include informational meetings for students organized well in advance of the course registration

TABLE III: Student responses to participant self-evaluation survey.

\begin{tabular}{|c|c|c|c|c|c|c|c|c|}
\hline \multirow[t]{2}{*}{ Participant Self-Evaluation } & \multicolumn{8}{|c|}{ Students } \\
\hline & $\# 1$ & $\# 2$ & \#3 & \#4 & $\# 5$ & \#6 & $\# 7$ & Total points (of 35 ) \\
\hline \multicolumn{9}{|c|}{ Instructions: Please rate your performance during the course $(1=$ lowest and $5=$ highest rating $)$} \\
\hline \multicolumn{9}{|l|}{ Participation } \\
\hline Contributes to discussion & 5 & 4 & 4 & 5 & 4 & 5 & 3 & 30 \\
\hline Asks appropriate questions & 5 & 4 & 4 & 4 & 4 & 4 & 3 & 28 \\
\hline Helps others & 4 & 4 & 4 & 4 & 4 & 3 & 3 & 26 \\
\hline \multicolumn{9}{|l|}{ Study habits } \\
\hline Spend quality time preparing & 3 & 3 & 4 & 4 & 4 & 4 & 4 & 26 \\
\hline Good note taking & 5 & 3 & 4 & 2 & 4 & 5 & 4 & 27 \\
\hline \multicolumn{9}{|l|}{ Group projects } \\
\hline Cooperate with group members & 5 & 4 & 5 & 5 & 4 & 3 & 4 & 30 \\
\hline Work together/share responsibilities & 5 & 4 & 5 & 5 & 4 & 3 & 4 & 30 \\
\hline Check for group's understanding & 5 & 4 & 5 & 5 & 4 & 3 & 4 & 30 \\
\hline \multicolumn{9}{|l|}{ Additional qualities/attributes } \\
\hline Enjoy class/course & 3 & 2 & 3 & 3 & 4 & 5 & 2 & 22 \\
\hline Tutor others & & 2 & & 1 & 4 & 3 & 2 & 12 \\
\hline Belief in own ability & 5 & 3 & 4 & 1 & 4 & 5 & 4 & 26 \\
\hline Desire to excel & 5 & 4 & 5 & 1 & 4 & 5 & 5 & 20 \\
\hline Overall personal rating & 5 & 4 & 4 & 3 & 3 & 4 & 4 & 27 \\
\hline
\end{tabular}


TABLE IV: Summary of selected students' remarks from the focus group discussion and instructors' assessment.

\begin{tabular}{|c|}
\hline RIGOR \\
\hline Student comments: \\
\hline $\begin{array}{l}\text {... Curriculum ... it was heavy. } \\
\text { Instructors challenged us with lots of work. Quizzes and homework had some of us struggling trying not to fall behind. I felt overwhelmed. } \\
\text { They [instructors] expected more study time. I don't think curriculum should be adjusted. Why should we not have high standards? For the res } \\
\text { of our lives we will encounter higher standards ... if we complain what are we saying? } \\
\text { Guest lectures too technical-vocabulary too technical. } \\
\text { I didn't like when they brought in Bloom's Taxonomy-Higher Level Thinking. }\end{array}$ \\
\hline $\begin{array}{l}\text { Students did not anticipate that the material, class format, and assessments would be as rigorous and technical as they experienced. In genera } \\
\text { students lacked fundamental analytical skills (i.e., calculating percentage, graphing) that were needed to complete the inquiry-based } \\
\text { activities. The technical level of many of the guest lectures exceeded the students' knowledge. Most students, although education } \\
\text { majors, appeared unfamiliar with the application of Bloom's taxonomy such that they did not recognize when these areas of critical }\end{array}$ \\
\hline
\end{tabular}

\section{2) Audience}

\section{Student comments:}

It [the course] should have been offered to majors.

[The class] need[s] to be geared toward elementary teachers also. Bring in a teacher to share how learning is applied in a real class.

Allow more students here to take this class. Historically Black Colleges and Universities need to expose/share information on such courses.

Let students decide to take class upon investigating the syllabus. Don't force students to take this course.

Instructors' assessment:

Students believed the course should have been structured differently in order to target elementary education majors. The original target audience for this course was preservice science teachers and science majors. The host university handled student recruitment. Enrollment in the course was low at the beginning of the semester. (The course was not included in the printed course catalogue for the semester.) At some point, students were recruited for the course primarily from education majors at the host university. We have a concern that one or more students may have anticipated a "rocks for jocks" type of course. Finally, although most of the students were education majors, they didn't appreciate that we were modeling inquiry though the use of hands-on, guided inquiry learning activities.

\section{3) BREADTH OF COURSE AND CURRICULUM FLEXIBILITY}

\section{Student comments:}

Good thing to have [Geosciences course]. This was a survey in the Geosciences. The course was a quick survey of many different things.

Good class ... geosciences.

They challenged us in totally different ways. [They] constantly gave us work. It got confusing. Topics [were] different each week. Syllabus was different. They changed things.

Adjusting curriculum-one thing 1 week and another in another week.

\section{Instructors' assessment:}

Whereas a few students appreciated the course as "a survey" of topics in the geosciences, many students found this challenging. As instructors adjusted the syllabus as the course progressed and items 1 and 2 above were taken into consideration, students were uncomfortable with these changes. The course was originally designed for preservice science teachers and science majors using a hands-on approach rather than direct teaching (lectures). As the course progressed, it became necessary to make adjustments to some of the inquiry-based activities, spending more time on topics than originally planned in the syllabus or removing activities from the syllabus altogether.

\section{4) BROADENING DIVERSITY IN THE GEOSCIENCES}

\section{Student comments:}

I think it [broadening diversity in the geosciences by providing geoscience education to preservice teachers and undergraduate students at Huston-Tillotson University, which is a minority serving institution] is a worthwhile endeavor. It could have been offered differently.

It [ibid] is a good thing.

Class is good. Minorities need to be exposed to [the] course.

It [the class] didn't meet its goal as I would have like to have seen somebody that looked like me.

No minorities... how as minority teacher ... there were no geoscientists, no pictures of Black or Hispanic geoscientists.

Void of minority in Geosciences.

I developed respect for Geoscientists.

\section{Instructors' assessment:}

Students clearly saw that there was a lack of diversity in the geosciences through their interactions with the instructors, guest speakers, and materials presented in class. Students developed a respect for the geoscience profession and those scientists who are active in the field. Because most of them will be minority-serving teachers, they should be able to pass this respect on to their students. Our students would have preferred minority instructors and a minority geoscientist as a guest speaker. 
deadline; presentations to STEM and education faculty, as well as one-on-one meetings with them, to apprise them of the goals and content of the course and solicit broad faculty support; inclusion in the course catalogue; and the widespread distribution of flyers advertising the course.

\section{We Were Visiting Faculty}

Two of our poor-performing students exhibited a poor attitude in the classroom, which was at times detrimental to the learning of the others present. It was difficult to know what stressors may have been operating or whether problems arose because we had not appreciated the importance of African American culture on the learning process (Costner et al., 2010). In the future, we would work with our hosts to help prepare us to recognize the unique characteristics and culture of African American students so that we could tailor the course for an HBCU audience as well as help us achieve better integration into the academic community at the host institution. In many respects, we have already made strides in this direction at HTU. Research shows that instructor engagement, positive experience with instructors, and the utilization of culturally appropriate pedagogy are important factors influencing minority student career choices and academic success (Levine et al., 2007; Brooker, 2009).

\section{Facilities}

We taught in a computer classroom because we thought it was the proper venue for the course we had planned. We learned, however, that it inhibited our teaching and student collaboration. Each student had a recessed computer monitor at their desk in order to permit them to use CD ROMs that we distributed with geoscience data for the learning activities and to access resources available at the Digital Library for Earth System Education Web site and tools such as UNAVCO's Jules Verne Voyager, Jr. This produced unanticipated problems with students checking email and surfing the Web during class. In retrospect, a room where groups could convene at large, movable tables might have been better. We can avoid this problem in the future by checking facilities well ahead of time and by identifying, requesting the most suitable room(s) for the course, and setting up laptop computers with Internet access for those activities that require them.

We also had a ceiling leak and a problem with the projection equipment, which took several class periods to rectify because of budgetary constraints. These unfortunate facility issues slowed the pace of the class or forced us to make last-minute changes in the syllabus. We can do more to anticipate these types of problems in the future and be prepared to help solve them. They are a reminder that smaller institutions may not have the same resources available as a large university such as University of Texas at Austin.

\section{Plagiarism}

We made assumptions that students were aware that cutting and pasting from Internet sources on homework assignments and final projects was unacceptable. For the most part, our assumptions were correct. However, the issue surfaced. In response, we prepared a document showing how to cite Web resources and email correspondence and gave students the opportunity to address problems stem- ming from plagiarism before a grade was awarded for homework assignments, reports, or projects. In the future, we would distribute this document with assignments and review the matter in class prior to assignments. Dealing with issues of plagiarism required great care and guidance from the faculty at the host institution.

\section{Teamwork}

In the beginning, the students did not like the idea of teamwork, including a group grade for projects and a selfassessment of individuals and other members of the individual's team. Several of the students in fact resisted ranking themselves or the others in their group. On the first group project, several of the teams lost points because they did not function well as a group. For the final project, the teamwork was much better, with students dividing up the work and participating more equally in the project. We believe that the performance of one of the teams in the first project helped raise the bar for the second and final project of the class. Fullilove and Treisman (1990) observed that while African American and other minority students underrepresented in STEM disciplines socialized with friends, they tended to work alone as students, a practice the authors felt robs them of support when solving problems and opportunities to share the intellectual excitement of their achievements. Some studies have shown that cooperative group work among African American students leads to improvements in both academic achievement and attitudes toward instruction and increases retention in demanding academic programs (Fullilove and Treisman, 1990; Felder and Brent, 1996).

\section{Critical Thinking Skills}

Most students continued to have difficulty with advanced critical thinking questions throughout the course. Because of this difficulty, we made changes in the syllabus so that we could spend several class periods reviewing student performance on the second quiz. Students had performed poorly on questions involving synthesis and analysis. We reviewed the quiz to discuss how an answer would reflect synthesis and analysis, and then the students were allowed to redo the quiz for grade revision. In hindsight, we would like to have had an education faculty member from HTU at different points during the course to emphasize the connection with Bloom's taxonomy, different pedagogical approaches, and various science standards.

\section{Students With Multiple Priorities and Obligations}

We were not aware at the onset of the course that students would have as many priorities and obligations as these nontraditional students did. Some students regularly missed all or part of class because of family, work, religious, or athletic team obligations. In particular, we were not fully cognizant of the importance of religion in the lives of our African American students. A recent special issue of the Journal of Negro Education edited by Witherspoon and Maydun (2010) contains a series of articles on the role of spirituality, religion, and the African American church on educational outcomes. Cultural sensitivity training would have been helpful in hindsight to minimize the challenges we faced. We applied lessons learned to the TeXas Earth and Space Science (TXESS) Revolution project. Specifically, we established a cyber café (TXESS Revolution Virtual Café) to 
permit teachers to access learning materials, log their daily reflections during their professional development activities, and interact with each other remotely at other times. This type of online learning community facilitates teamwork, emphasizes individual and group responsibility and accountability, and helps participants and instructors to better coordinate activities and share information, especially in cases of unavoidable absence.

\section{Role Models}

Particularly noteworthy were students' comments that the films assigned for the final team project, "Science and a Movie," did not include scientists whom they could regard as role models. One student remarked: "No one looks like me." Similarly, we were unable to find minority guest presenters from among the Jackson School faculty and research staff at the time that we taught the course, although we included several women speakers. In addition, two students appeared to have difficulty with us as nonminority authority figures. Although a minority host scientist was present much of the time in the classroom, this professor was not involved in teaching the course. We have made efforts to address the issue of role models in the TXESS Revolution teacher professional development program by inviting scientists who are themselves minorities underrepresented in the geosciences, especially by working in collaboration with programs such as the National Association of Geoscience Teachers Distinguished Speaker Series as well as the Department of Petroleum and Geosystems Engineering at University of Texas at Austin and the Texas Water Development Board, a state agency.

\section{Analytical Skill Set}

Many of the students' analytical skills had a poor foundation. This required us to take time from the planned syllabus to focus on basic skills, such as plotting points on an $x-y$ graph and calculating a percent. The need for remedial work in mathematics at the college level for minority students and the call for institutional reforms to address the persistent achievement disparities are recurring themes in the research literature and reports (Fullilove and Treisman, 1990; Bandura, 1997; Lubienski, 2002; National Academies, 2010; Snow, 2010).

\section{BROADER IMPACTS}

One HTU preservice teacher worked as an intern at UTIG during the summer and fall of 2006. Her primary responsibilities included helping three UTIG researchers transform their research into education materials. The student also (1) adapted approximately 10 existing UTIG Earth science learning activities into the 5-E instructional model for a series of professional development academies, Earth Science Revolution Workshops, that we provided minority-serving in-service teachers in fall 2006 and (2) helped with the delivery of these same professional development academies (e.g., presenting her "Science and a Movie" project to the in-service teachers). She attended a meeting of the American Geophysical Union (AGU) to give a poster and participate in AGU's Geophysical Information for Teachers workshop. She also helped present a workshop for Austin Independent School District's minority-serving elementary school teachers and a class for alternative certification teachers at HTU. In early September, she joined a group of scientists, engineers, and astronauts in the Arizona desert near Meteor Crater to "practice" for future human missions to Mars as a participant in NASA's Desert Research and Technology Studies project. Her role was to help scientists and engineers with experiments to determine the efficacy of ground-penetrating radar in locating buried ice (water) and other resources, such as metals, and to translate the experience into $\mathrm{K}-12$ classroom activities. In addition, Dr. Muchere Russ, HTU faculty and coprincipal investigator on the project, sat in on the special topics course, which helped expand this preservice teacher's knowledge of geoscience and of its fit with other STEM disciplines taught at HTU.

This student's experience as an intern exposed her to prominent geoscientists and science educators. The immersion in science, the opportunities to be part of scientific research teams, daily interaction with scientists and graduate students at UTIG, the mentoring from research scientists at UTIG, and the respect shown to her for transforming their science into interesting projects for $\mathrm{K}-12$ students and teachers contributed to this student's decision to pursue science teaching as a career. She is currently teaching in a magnet school in Houston, Texas, and is considering graduate studies.

Many research scientists at UTIG interacted with our HTU student intern and learned about the relevance of their work to the $\mathrm{K}-12$ community. They were impressed by the intern's abilities, creativity, enthusiasm for geoscience, and work ethic. This has increased their willingness to host other pre- or in-service science teachers and provided insight on how to make their science more interesting and relevant for $\mathrm{K}-12$ audiences.

Our experience at a minority-serving institution enabled us to apply the valuable learned lessons to launch a successful program of geoscience professional development for minority and minority-serving in-service science teachers-the TXESS Revolution-with NSF, corporate, and institutional support. Now in its final year, the TXESS Revolution has successfully served over 170 educators though ongoing professional development; these teachers in turn have directly influenced approximately 20,000 students of which $67 \%$ are minorities (Ellins et al., 2010).

\section{CONCLUSIONS}

The project contributed to the research and teaching skills and experience of the undergraduate HTU students who took "Special Topics in the Geosciences" by exposing them to high-quality and rigorous Earth science materials, geoscientists conducting cutting-edge research in the field, a survey of headliner topics in the geosciences, and pedagogical approaches to teaching inquiry. Texas students' performance on Earth science is far lower than any of the other science disciplines tested and underscores the desperate need to better prepare teachers in Earth and space science. Although the problems and pitfalls faced may have limited the success of the course, the project contributed in a small way to the preparation of minority teachers to teach Earth science in Texas, filling a critical need.

The authors were compelled to consider how to improve collaboration with an HBCU and revise their approach to teaching minority undergraduate and preservice teachers. 
Lessons learned about the unique characteristics and culture of the host institution and the student audience, and a deeper appreciation of the priorities and obligations of nontraditional students led to the subsequent design and success of the TXESS Revolution project.

\section{Acknowledgments}

The authors would like to thank Dr. Muchere Russ for hosting us as guest instructors at HTU and Dr. Deanna Mercer for facilitating the focus groups. The National Science Foundation's Opportunities for Enhancing Diversity in the Geosciences program funded the special topics course at HTU as part of the UTIG/HTU Geodiversity Project under grant NSF GEO-0503508. Institutional support from the Jackson School of Geosciences funded the guest presenters and an undergraduate research experience for an HTU student. Special thanks to Dr. John Holt who served as the science mentor for the HTU student intern and supported her participation in NASA's Desert Research and Technology Studies project.

\section{REFERENCES}

Bandura, A. 1997. Self-efficacy: The exercise of control. New York: W.H. Freeman and Company.

Barry, C.L., Horst, S.J., Finney, S.J., Brown, A.R., and Kopp, J.P. 2010. Do examinees have similar test-taking effort? A highstakes question for low-stakes testing. International Journal of Testing, 10:342-363.

Bertog, J.L. 2007. Student evaluation of cities' hazards and benefits for company relocation: An introductory geology class project in educated citizenship. Journal of Geoscience Education, 55:2835 .

Bloom, B. 1956. Taxonomy of educational objectives: The classification of educational goals. Handbook I: The cognitive domain. New York: David McKay Company, Inc.

Boyd, S.E., Banilower, E.R., Pasley, J.D., and Weiss, I.R. 2003. Progress and pitfalls: A cross-site look at local systemic change through teacher enhancement. Available at http://www. horizon-research.com/reports/2003/progress_and_pitfalls.php (accessed 3 October 2006).

Brooker, N.M. 2009. Cultural competence: Educating public school teacher candidates in matters of diversity [Ph.D. thesis]. Akron: University of Akron.

Business Roundtable. 2005. Tapping America's potential: The education for innovation initiative. Washington, DC: Business Roundtable. Available at http://www.tap2015.org/about/ TAP_report2.pdf (accessed 9 January 2006).

Bybee, R.W., Taylor, J.A., Gardener, A., Van Scotter, P., Powell, J.C., Westbrook, A., and Landes, N. 2006. The BSCS 5E instructional model: Origin, effectiveness, and applications. Available at http://www.bscs.org/pdf/bscs5eexecsummary.pdf (accessed 8 January 2012).

Committee on Prospering in the Global Economy of the 21st Century: An Agenda for American Science and Technology, National Academy of Sciences, National Academy of Engineering, Institute of Medicine. 2007. Rising above the gathering storm: Energizing and employing America for a brighter economic future. Washington, DC: National Academies Press.

Costner, K.L., Daniels, K., and Clark, M.T. 2010. The struggle will not continue: An examination of faculty attitudes toward teaching African American students. Journal of Black Studies, 41:40-55.

Czujko, R., and Henly, M. 2003. Good news \& bad news: Diversity data in the geosciences. Geotimes, September 2003:20-22.

Ellins, K.K., and Olson, H. 2000. From Texas to Antarctica: A voyage of intrigue and discovery. Geology, Meteorology, and Oceanography TEXTEAMS Leadership Training Institute Manual. Austin, TX: UTIG.

Ellins, K.K., Olson, H., and Pulliam, J. 2002. Geophysical data in the classroom: Examples from TEXTEAMS GMO and the catastrophes project. EOS Trans. AGU, 83(47), Fall Meet. Suppl., Abstract ED71C-02.

Ellins, K.K., Olson, H.C., Snow, E., Odell, M., Stocks, E., and Willis, M. 2010. The impact of the Texas Earth and Space Science (TXESS) revolution. Geological Society of America Abstracts with Programs, 42(5):Paper No. T43-133-1.

Felder, R.M., and Brent, R. 1996. Navigating the bumpy road to student-centered instruction. College Teaching, 44:43-47.

Fullilove, R.E., and Treisman, P.U. 1990. Mathematics achievement among African American undergraduates at the University of California Berkeley: An evaluation of the mathematics workshop program. Journal of Negro Education, 593:463-478.

George, Y.S., Neale, D.S., Van Horne, V., and Malcolm, S.M. 2001. In pursuit of a diverse science, technology, engineering, and mathematics workforce: Recommended research priorities to enhance participation by underrepresented minorities, American Association for the Advancement of Science Report 1/ AGEP. Available at http://ehrweb.aaas.org/index.shtmal (accessed 6 September 2004).

Grigg, W.S., Lauka, M.A., and Brockway, D.M. 2006. The nation's report card: Science 2005. U.S. Department of Education, National Center for Education Statistics. Washington, DC: U.S. Government Printing Office, NCES 2006-466.

Hall, F.R., and Johnson, R.M. 2001. Diversity in the geosciences: Issues, information, and the role of the American Geophysical Union. EOS Trans. AGU, 82(47), Fall Meet. Suppl., Abstract ED21B-0192.

Huntoon, J.E., and Lane, M.J. 2007. Diversity in the geosciences and successful strategies for increasing diversity. Journal of Geoscience Education, 55:447-457.

Karsten, J. 2003. A unified approach to diversifying the Earth sciences. Geotimes, September 2003. Available at http://www. geotimes.org/sept03/feature_diversity.html (accessed 8 January 2012).

Kaser, J.S., and Bourexis, P.S. 1999. Enhancing program quality in science and mathematics. Thousand Oaks, CA: Corwin Press, Inc.

Levine, R., Gonzalez, R., Cole, S., Fuhrman, M., and Le Floch, K.C. 2007. The geoscience pipeline: A conceptual framework. Journal of Geoscience Education, 55:458-468.

Loucks-Horsley, S., Hewson, P., Love, N., and Stiles, K.E. 1998, Designing professional development for teachers of science and mathematics, Thousand Oaks, CA: Corwin Press, Inc.

Lubienski, S.T. 2002. A closer look at black-white mathematics gaps: Intersections of race and SES in NAEP achievement and instructional practices data. Journal of Negro Education, 71:269287.

National Academies. 2010. Expanding underrepresented minority participation: America's science and technology talent at the crossroads. Washington, DC: National Academy Press.

National Research Council. 1996. National science education standards. Washington, DC: National Academy Press.

National Science Board. 2003. The science and engineering workforce: Realizing America's potential (NSB 03-69). Arlington, VA: National Science Foundation.

National Science Foundation. 2005. Geoscience education and diversity: Vision for the future and strategies for success. Report of the Second Geoscience Education Working Group, September 2005. Available at: http://www.nsf.gov/geo/adgeo/ geoedu/GEWGII_Report_sept_2005.pdf (accessed 3 October 2006).

Putman, N., Ellins, K., Holt, J., and Olson, H.C. 2006. My experience as a student participant in the Institute for Geophysics/Huston-Tillotson University geodiversity project. 
EOS Trans. AGU, 86 (52), Fall Meet. Suppl., Abstract ED51A0830.

Riggs, E., and Alexander, C., eds. 2007. Broadening participation in the earth sciences-Special Edition. Journal of Geoscience Education, 55.

Rodgers, J., Cano, J., Ellins, K. 2005. Drought and Mayan civilization collapse: ODP Core 1002D and a GK-12 climatology activity, enhancing K-12 science education and graduate student professional development. Salt Lake City, UT: American Society of Limnology and Oceanography, TS45.

Smyth, B., Ellins, K., Bonal, N., Heppner, T., Morris, M., Christeson, G., Gulick, S. Dinan, M., Fennell, T., and Thomas, D. 2003. Cataclysms and catastrophes: Engaging students to address real-world situations using scientific data analysis. Geological Society of America Abstracts with Programs, 35(6), 123, A4653.

Snow, E. 2010. GeoFORCE Texas: Successfully delivering a diverse group of students to college STEM fields-What next? Geological Society of America Abstracts with Programs, 42(5), paper no. T43-133-5.

Svihla, V., Ellins, K., and Fennell, T. 2004. Effective problem-based activities: Imparting content and learning skills through a debate on the K-T extinction event. Geological Society of America Abstracts with Programs, 36(4): 89, paper no. 40-8.

Texas Education Agency. 2009. Texas administrative code (TAC), title 19, part II, chapter 112. Texas essential knowledge and skills for science. Available at http://ritter.tea.state.tx.us/rules/ tac/chapter112/index.html (accessed 21 March 2011).

Texas Education Agency, Division of Performance Reporting. 2005.

Texas public school statistics, pocket edition, 2004-05.

Publication number BR06 602 01. Austin, TX: Texas Education Agency.

Texas Education Agency, Division of Performance Reporting. 2007. Texas public school statistics, pocket edition 2006-07. Available at http://ritter.tea.state.tx.us/perfreport/pocked/2007/ pocked0607.pdf (accessed 15 November 2010).

Texas Education Agency, Division of Performance Reporting. 2011. Texas public school statistics, pocket edition 2009-2010. Available at http://ritter.tea.state.tx.us/perfreport/pocked/ 2010/pocked0910.pdf (accessed 8 January 2012).

Texas Education Agency Earth Science Task Force. 2003. Report of the Earth Science Task Force, June 2003. Available at http:// www.tea.state.tx.us/sboe/schedule/1103/earthsciatt1.html (accessed 5 September 2004).

United Negro College Fund. 2011. About us. Available at http:// www.uncf.org/aboutus/hbcus.asp (accessed 30 July 2009).

United States Department of Education. 2009. White House Initiative on Historically Black Colleges and Universities. Available at: http://www.ed.gov/about/inits/list/whhbcu/ edlite-list.html (accessed 30 July 2009).

Witherspoon, N., and Maydun, N., eds. 2010. The role of spirituality, religion and the African American church on educational outcomes. Journal of Negro Education, 79:199-444. 